\title{
Discussion on the Judgment of the Optional Capital Structure -- A Case Study of X Company
}

\author{
Chenghan Li*, Siyi Wang \\ The University of Sydney, Sydney NSW5020, Australia
}

\begin{abstract}
Optimization of capital structure has been a famous issue in Corporate Finance. It is essential for modern companies to find the optional capital structure of themselves because it could help these companies to reduce the cost of finance. This best structure is not easy to find out due to the complex determinants behind it. However, there still are some alternative ways could be used to judge whether a company reach its optional capital structure. This report takes X company as an example to discuss that how to use different efficient methods to estimate the optional capital structure of a company.
\end{abstract}

Keywords: Ratio analysis; Peer company comparison; Trade-off theory

Publication date: April, 2021; Publication online: 30 April, 2021

*Corresponding author: Chenghan Li, chenghan_li@,163.com

\section{Introduction}

Capital structure is important for companies in daily operation and increasingly concerned by managers. This report analyses the capital structure of $\mathrm{X}$ company by ratio analysis and compare this firm's capital structure with other companies in same industry. In addition, based on the comparation and optimal capital structure theories, we found $\mathrm{X}$ company is operating at its optimal capital structure and then analyses potential reasons.

\section{The analysis of $X$ 's capital structure}

\subsection{Company overview}

$\mathrm{X}$ is a New Zealand-based utility firm whose major businesses operated in Australia, New Zealand and the United States (Morning Star Data Analysis Premium Report, 2019). According to the company's annual report released in 2019, the operating revenue of $\mathrm{X}$ from infrastructure and utilities is $\$ 1276.77$ million. Overall, the firm's total assets in 2019 is \$ 6448.09 million and the total liabilities and equity in 2019 are \$3818.71 million and \$2629.38 million, respectively.

\subsection{The capital structure of $X$}

\subsubsection{Data}

According to Florackis and Ozkan(2009), book values are more accurate when analysing a financial structure because the volatility of book values are less than market values. As a result, book values on balance sheet and financial statements of X from 2015 to 2019 are used to analyse this firm's capital structure. In addition, MorningStar DatAnalysis database is used to collect financial data.

\subsubsection{Methodology}

Debt-to-equity ratio is used in this report to measure the capital structure of companies.

According to Michael (2015), debt-to-equity ratio compares a company's total liabilities with this company's total equity and this ratio is regarded as a good reflection of the capital structure of a firm because debt-to-equity ratio measures the proportion between equity and liabilities which are two major capital sources. In general, a high $\mathrm{D} / \mathrm{E}$ ratio means the capital funding of a firm mainly from debt instead of equity, which could increase financial risk. However, the $\mathrm{D} / \mathrm{E}$ ratios in different sectors are extremely different and utility industry is considered to have a relative higher debt-to-equity ratio compared with other sectors.

However, traditional debt-to-equity ratio (Total liabilities/Total equity) could not accurately measure the capital structure of a company. This is because capital structure mainly influenced by interest-bearing debt rather than total liabilities (Titman et al., 2011). As a result, this report makes an adjustment to debt-to-equity ratio, which means only interest-bearing debts are used to analyse the capital structure rather than total liabilities.

The formula of adjusted debt-to-equity ratio is: 
DEBT - TO $-E Q U I T Y R A T I O=\frac{\text { Interest-bearing liabilities }}{\text { Total Shareholders'Equity }}$

(1) Based on above-mentioned analysis, we calculate the

2.2.3 Capital structure

Table 1. Debt-to-equity ratio of X from 2015 to 2019

\begin{tabular}{cccc}
\hline YEAR & Interest-bearing liabilities & Equity & Debt-to-equity ratio \\
\hline 2015 & $\$ 2551.54$ million & $\$ 2506.42$ million & $101.80 \%$ \\
2016 & $\$ 2340.90$ million & $\$ 2765.77$ million & $84.64 \%$ \\
2017 & $\$ 2565.11$ million & $\$ 2868.40$ million & $89.43 \%$ \\
2018 & $\$ 2505.17$ million & $\$ 2942.61$ million & $85.13 \%$ \\
2019 & $\$ 2845.81$ million & $\$ 2629.38$ million & $108.23 \%$ \\
\hline
\end{tabular}
the data (Table 1).

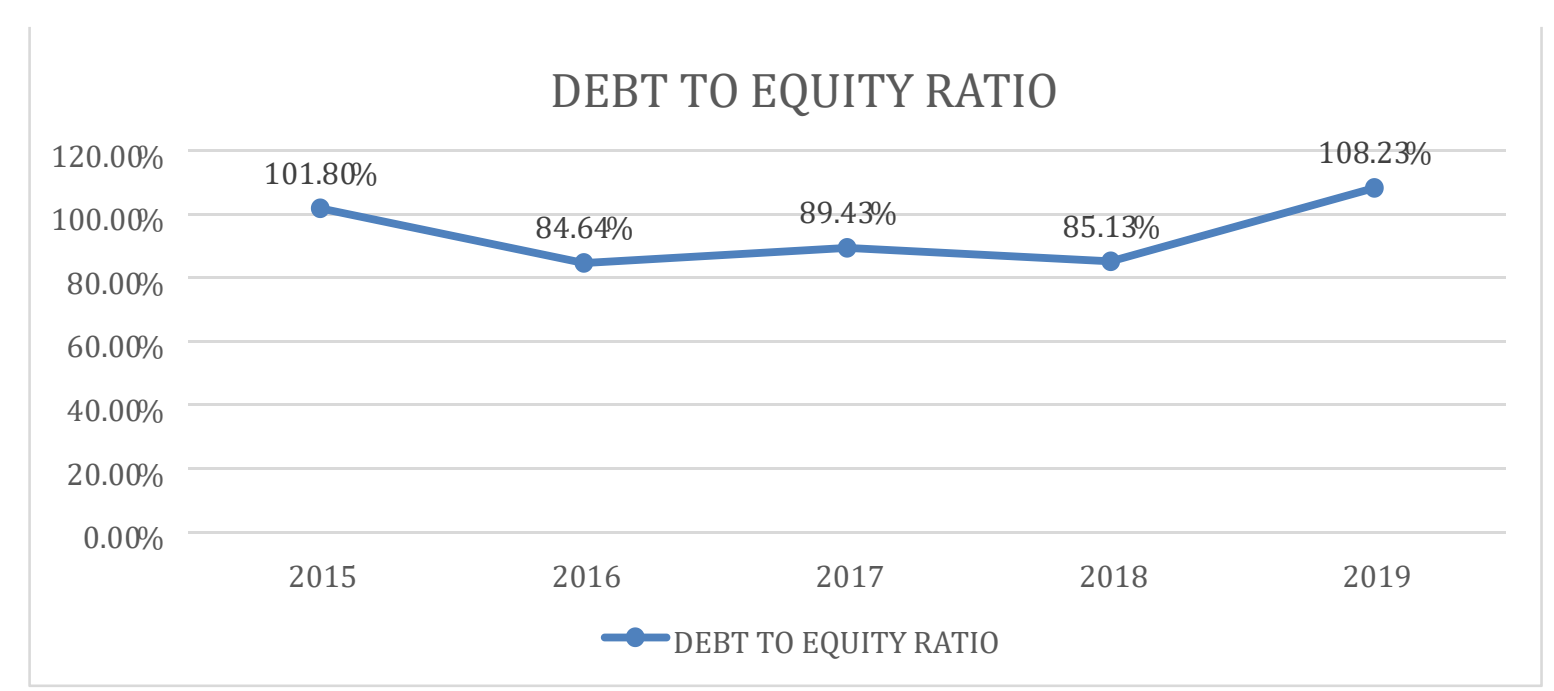

Figure 1. Debt to equity ratio

This figure shows that over the past 5 years, D/E ratios of $\mathrm{X}$ keep a high and flat level in general. However, there are fluctuations shown in the chart and the $\mathrm{D} / \mathrm{E}$ ratios in 2015 and 2019 are higher than the ratios in other 3 years (Figure 1).

\section{The capital structure of other companies in the same industry}

\subsection{Data}

According to Albuquerque (2009), in order to establish an ideal peer group, companies in the peer group should have similar size, financial constraints, sectors, business, markets, and diversification. Based on these characteristics, 4 electric utility companies $\mathrm{Y}, \mathrm{Z}, \mathrm{W}$, and $\mathrm{N}$ are used to compare with $\mathrm{X}$. In addition, the average data of these 4 companies are used as industry average to compared with X. Similarly, MorningStar database is used to collect data and adjusted $\mathrm{D} / \mathrm{E}$ ratio is used to measure capital structure.

\subsection{Capital structure}

According to the $\mathrm{D} / \mathrm{E}$ ratio formula and financial data gathered from MorningStar DatAnalysis database, D/E ratio of 4 companies from 2015 to 2019 are calculated and present in below table (Table 2).

Table 2. D/E ratio of 4 companies from 2015 to 2019

\begin{tabular}{ccccccc}
\hline YEAR & Y & Z & W & N & AVERAGE & X \\
\hline 2015 & $35.27 \%$ & $52.49 \%$ & $55.19 \%$ & $75.60 \%$ & $54.64 \%$ & $101.80 \%$ \\
\hline
\end{tabular}




\begin{tabular}{lllllll}
\hline 2016 & $35.51 \%$ & $45.81 \%$ & $60.08 \%$ & $46.99 \%$ & $47.10 \%$ & $84.64 \%$ \\
2017 & $33.46 \%$ & $63.57 \%$ & $55.03 \%$ & $37.27 \%$ & $47.33 \%$ & $89.43 \%$ \\
2018 & $39.71 \%$ & $64.00 \%$ & $54.46 \%$ & $141.71 \%$ & $74.97 \%$ & $85.13 \%$ \\
2019 & $34.86 \%$ & $59.97 \%$ & $39.40 \%$ & $46.05 \%$ & $45.07 \%$ & $108.23 \%$ \\
\hline
\end{tabular}

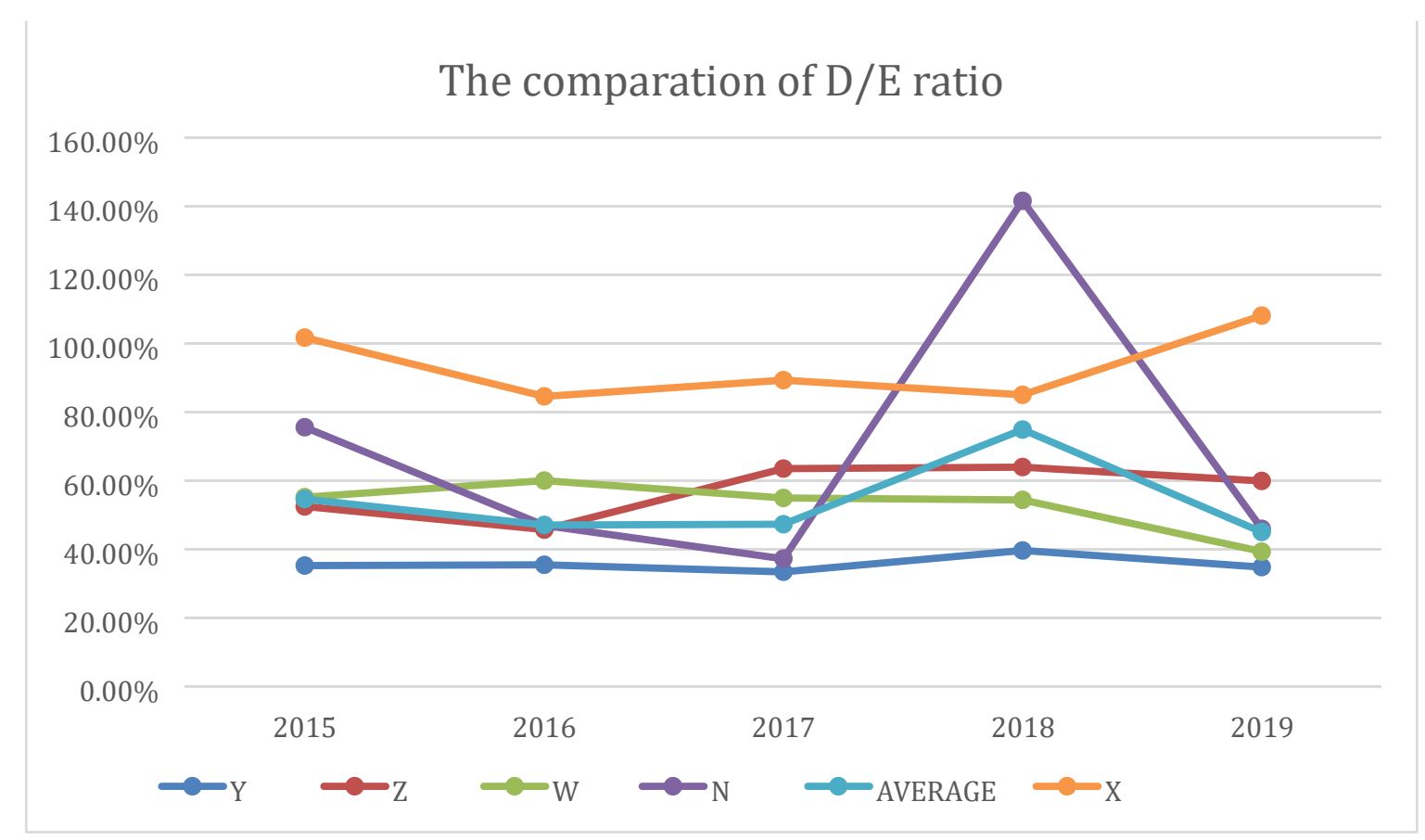

Figure 2. The comparation of $\mathrm{D} / \mathrm{E}$ ratio

In general, above figure shows that the trend of different company's $\mathrm{D} / \mathrm{E}$ ratio is flat expect $\mathrm{N}$ and most companies have similar D/E ratio. Compared $\mathrm{X}$ with other companies and industry average, the $\mathrm{D} / \mathrm{E}$ ratio of $\mathrm{X}$ is higher than the industry average and other companies. This means $\mathrm{X}$ has a higher debt level than other companies (Figure 2).

\section{Optimal capital structure}

Capital structure measures the proportion of various sources of capital used by companies to maintain their growth and operations. Capital structure is increasingly concerned by firms because it influences the cost of capital which finally effects the value of companies. In order to maximize the value of firms, managers adjust the proportion of different capital funds to minimise the cost of capital and the capital structure that can maximize the value of company is called optimal capital structure.

The theory of capital structure is first developed by Modigliani and Miller in 1958.
Modigliani and Miller (1958) state that the firm value is not influenced by its capital structure based on following assumptions:

- All market participants can acquire the same information.

- There are no corporate taxes or personal income taxation.

- Trading shares does not generate costs.

- The borrow rate of investors is same as the firm.

Based on above-mentioned theory, there is no optimal capital structure. This is because Corporate value is constant regardless of the capital structure.

However, Modigliani and Miller corrected their theory in 1963 and introduced the effect of taxes on the value of companies. According to Modigliani and Miller (1963), in order to enlarge tax shield, companies should use debt as much as possible because tax shield can increase the value of companies. This theory can be represented by following formula: 


$$
V^{L}=V^{U}+P V(\text { Interest Tax Shield })
$$

Above-mentioned theory and formula show that the optimal capital structure under MM proposition with tax is to use $100 \%$ debt as capital funding. However, Modigliani and Miller only consider the benefit of tax shield but ignore the risk of debt. As a result, based on MM theory, the trade-off theory is developed. According to Acaravci (2015), the assumption of trade-off theory is that the trade-off between the costs and benefits of debt could be used to measure capital structure. Trade-off theory believes that the costs of financial distress rises with the increase of debt. In addition, the agency costs or benefits between the stakeholders can also influence the capital structure (Acaravci, 2015). As a result, trade-off theory and agency cost theory can be represented by following formula:

$V^{L}=V^{U}+P V($ Interest Tax Shield $)-P V($ Financial Distress Costs $)$ - PV(Agency Costs of Debt $)+$ PV (Agency Benefits of Debt)

According to above formula, there could be an optimal capital structure when the cost of bankruptcy is large than 0 and there is an agency benefits of debt. Although trade-off theory has become one of the main theories of capital structure, Miller (1977) argues that the cost of agency and financial distress are too small, which could not influence the benefit of tax shield. As a result, in future, the theory of optimal capital structure maybe still needs to be developed.

\section{The optimal capital structure of $X$}

\subsection{Model selection}

This report analyses the optimal capital structure of X based on trade-off theory.

The formula of trade-off theory is:

$V^{L}=V^{U}+P V($ Interest Tax Shield $)-P V($ Financial

Distress Costs)

$V^{U}$ in this formula is constant. As a result, this report only analyses the relationship between PV (Interest Tax Shield) and PV (Financial Distress Costs).

\subsection{Data}

The data use in this part from balance sheet of $\mathrm{X}$ released on MorningStar DatAnalysis database in 2019. This report also assumes some other potential capital structure in 2019 to compare with the current capital structure, which could help $\mathrm{X}$ to find whether this company is at its optimal capital structure.

\subsection{The present value of interest tax shield}

According to Ross, Westerfield and Jaffe (2008), we assume that the interest of debt and the cash flow have the same risk.
As a result, interest rate could be used as the discount rate of interest tax shield. Assume that $\mathrm{R}$ is interest rate and $\mathrm{D}$ is the amount of debt and $\mathrm{T}$ is corporate tax rate. As a result, the interest is $R^{*} D$ and the interest tax shield can be represented by $\mathrm{R} * \mathrm{D} * \mathrm{~T}$. Based on above assumptions, the present value of interest tax shield is:

The present value of interest tax shield $=\frac{R * D * T}{R}$

As a result, the present value of interest tax shield is D*T. According to Australian Taxation Office, the tax rate of corporate tax is $30 \%$.

\subsection{The present value of financial distress costs}

According to Bar-Or (2000), an expected financial distress costs of a health company is $8 \%$ to $10 \%$ of its value. In this report, $10 \%$ is used to calculate the financial distress cost because the $\mathrm{D} / \mathrm{E}$ ratio is higher than industry average, which could incur higher financial distress costs. Due to the data used in this report is in current year (2019), the estimate financial distress cost is equal to $0.1 *$ value.

\subsection{Calculation assume}

Calculation assume that:

- $\mathrm{D}$ is the value of debt.

- $E$ is the value of equity.

$-\mathrm{V}$ is the value of company

- $\mathrm{Z}$ is the difference between interest tax shield and financial distress cost. According to these assumptions, the present value of interest tax shield is $0.3 * \mathrm{D}$ and the present value of financial distress cost is $0.1^{*}(\mathrm{D}+\mathrm{E})$. Thus,

$\mathrm{Z}=0.3 * \mathrm{D}-0.1 *(\mathrm{D}+\mathrm{E})$

$$
\begin{gathered}
\mathrm{Z}=0.3 * \mathrm{D}-0.1 * \mathrm{D}-0.1 * \mathrm{E} \\
\mathrm{Z}=0.2 \mathrm{D}-0.1 \mathrm{E} \\
\mathrm{D}<\mathrm{V}
\end{gathered}
$$

If $0.2 \mathrm{D}$ large than $0.1 \mathrm{E}$, debt could add value to company. Otherwise, debt would cause financial distress. The value of debt of $\mathrm{X}$ is $\$ 2845.8$ million and the value of equity is $\$ 2629.38$ million. $0.2 * \$ 2845.8$ million is equal to $\$ 569.16$ million and $0.1 * \$ 2629.38$ million is equal to \$262.94 million, which satisfy above formula. This means that the current proportion between debt and equity could increase the value of firm. However, accurate optimal capital structure cannot be calculated based on above method. This is because it is extremely difficult to estimate the financial distress costs of a company with health financial condition (Ross et al., 2008).

Furthermore, according to part 2, we compare $\mathrm{X}$ with other companies in same sector and industry average. The $\mathrm{D} / \mathrm{E}$ ratio of $\mathrm{X}$ is higher than other companies and industry 
average. According to MorningStar DatAnalysis Premium Report (2019), the total assets of $X$ also large than the total assets of its peer group. As a result, $X$ approach or is at its optimal capital structure.

\section{Conclusion}

Above-mentioned theories and methods suggest that, the capital structure of $\mathrm{X}$ is better than its peer group and it is believe that this company approach or is at its optimal capital structure. However, there are some limitations in this report. Firstly, the sample size of peer group is small because of the constraint of selection rules, which could lead to an inaccuracy result. Secondly, due to the difficulty of calculating the present value of financial distress costs, the quantity method used in this report cannot acquire an accurate optimal capital structure. In future, related research job could focus on the financial distress costs of a company with health financial condition. In addition, if there are more comparable companies under the rules of selection, the result could be more accurate.

\section{References}

[1] Acaravci, S. K. (2015). The determinants of capital structure: Evidence from the Turkish manufacturing sector. International Journal of Economics and Financial Issues, 5(1), 158-171.

[2] Albuquerque, A. (2009). Peer firms in relative performance evaluation. Journal of Accounting and Economics, 48(1), 69-89.

[3] Bar-Or, Y. D. (2000). An investigation of expected financial distress costs.

[4] Florackis, C., \& Ozkan, A. (2009). Managerial incentives and corporate leverage: evidence from the United Kingdom. Accounting \& Finance, 49(3), 531-553.

[5] Michael, R. (2015). Ratios Description. In Financial Ratios for Executives (pp. 7-105). Apress, Berkeley, CA.

[6] Miller, M. 1-1., 1977. Debt and Taxes, Joumal of Finance, 31, 261-275.

[7] Modigliani, F., \& Miller, M. H. (1958). The cost of capital, corporation finance and the theory of investment. The American, 1, 3.

[8] Modigliani, F., \& Miller, M. H. (1963). Corporate income taxes and the cost of capital: a correction. The American economic review, 53(3), 433-443.
[9] MorningStar DatAnalysis Premium Report. (2019). Retrieved October 23, 2019, from https://datanalysis-morningstar-com-au.ezproxy1.librar y.usyd.edu.au/af/dathome? $x$ tmlicensee=datpremium

[10] Ross, S., Westerfield, R., \& Jaffe, J. (2008). Corporate finance (8th ed.). Boston: McGrawHill/Irwin.

[11] Titman, S., Keown, A. J., Martin, J. D., \& Martin, T. (2011). Financial management: Principles and applications (Vol. 11). Boston: Prentice Hall. 